\title{
WPLYW ANEKSOWANIA TERMINU UMOWY NA PROGNOZĘ KOSZTU REALIZACJI W METODZIE WARTOŚCI WYPRACOWANEJ
}

\author{
Mieczysław Połoński ${ }^{\bowtie}$ \\ Wydział Budownictwa i Inżynierii Środowiska, Szkoła Główna Gospodarstwa Wiejskiego w Warszawie, Warszawa
}

\begin{abstract}
STRESZCZENIE
Metoda wartości wypracowanej (ang. earned value method - EVM) jest coraz powszechniej uznawanym narzędziem służącym do kontroli realizacji robót budowlanych zarówno w wymiarze rzeczowym, jak i finansowym. Jedną z cennych możliwości tej metody jest prognozowanie kosztu końcowego robót na podstawie dotychczasowego zaawansowania robót i poniesionych nakładów finansowych. Podczas realizacji inwestycji często występują opóźnienia ustalonego w umowie o roboty budowlane terminu zakończenia prac, co skutkuje podpisaniem aneksu. Może on dotyczyć przesunięcia terminu zakończenia, zmiany zaplanowanych kosztów wykonania lub jednego i drugiego równocześnie. W artykule podniesiono problem wpływu zmiany planowanego terminu zakończenia robót na obliczenie prognozy jego kosztu końcowego. Jak wykazano na przykładach, sposób uwzględnienia w EVM zmiany terminu ma istotny wpływ na wynik prognozy. W artykule wskazano zalecane rozwiązanie, pozwalające na niezbędną modyfikacje harmonogramu i poprawne szacowanie kosztu końcowego.
\end{abstract}

Słowa kluczowe: obiekt budowlany, wartość wypracowana, EVM, prognoza kosztów, aneksowanie, kontrola przedsięwzięć budowlanych

\section{WSTĘP}

Metoda wartości wypracowanej (ang. earned value method - EVM) została stworzona w celu kontroli postępów robót podczas realizacji różnego rodzaju projektów, w tym budowlanych (Webb, 2008; Czarnigowska, Jaskowski i Biruk, 2011; Baumann, Dziadosz, Kapliński i Rejment, 2014; Dziadosz, Tomczyk i Kapliński, 2015; Połoński, 2015). Znając planowany koszt całkowity robót (BAC - ang. budget at completion) i czas wykonania ( $P D$ - ang. planned duration), po oszacowaniu kosztów rzeczowego postępu robót ( $E V$ - ang. earned value), porównaniu go $\mathrm{z}$ wartościami zaplanowanymi $\mathrm{w}$ okresie objętym aktualizacją (PV - ang. planned value) oraz po zebraniu danych o rzeczywistych kosztach wykonanych robót $(A C-$ ang. actual cost), planista jest w stanie obliczyć m.in. dwa podstawowe wskaźniki świadczące o realnym postępie prac. Pierwszy z nich to tzw. CPI (ang. cost performace index - wskaźnik wykorzystania kosztu). Oblicza się go jako stosunek $E V$ do $A C$, czyli wskaźnik ten oznacza, jaka część kosztów została poniesiona zgodnie z planem. Jeżeli $C P I<1$, oznacza to, że koszt robót wykonanych jest większy niż planowano. Jeżeli $C P I>1$, świadczy to, że koszt robót wykonanych jest mniejszy niż planowano. Drugim często używanym wskaźnikiem jest wskaźnik SPI (ang. schedule performance index - wskaźnik wykonania harmonogra$\mathrm{mu})$. Oblicza się go jako stosunek $E V$ do $P V$ i jest to wskaźnik wykonania harmonogramu w funkcji czasu. 
Wartość $S P I<1$ oznacza opóźnienie prac w stosunku do planu, $S P I>1$ wskazuje na szybsze tempo wykonywania prac w stosunku do planu. Należy zwrócić uwagę, że wskaźnik SPI pomimo że jest używany do obliczania tempa robót (a więc czasu), obliczany jest na podstawie kosztów.

Twórcy EVM szybko zauważyli, że skoro już po pewnym zaawansowaniu robót można wyliczyć, czy realizacja robót przebiega zgodnie z planem, to w przypadku gdy tak nie jest, ostateczny koszt i termin wykonania robót prawdopodobnie będą inne niż zaplanowano (Webb, 2008; Ziółkowska i Połoński, 2018). I tu się rodzi pytanie: $w$ takim razie jakie to będą wartości? Odpowiedź na to pytanie nie jest prosta, jak w większości przypadków dotyczących prognozowania przyszłości. Powstało wiele formuł obliczeniowych służących do wyznaczania prognozowanego całkowitego kosztu zakończenia robót, tzw. $E A C$ (ang. estimated at completion) oraz całkowitego czasu wykonania robót, tzw. ETTC (ang. estimated time at completion). W znacznej mierze wybór właściwej formuły obliczeniowej zależy od zakładanego scenariusza tempa i realnych kosztów prac, które pozostały do zrealizowania. Wielu autorów wychodzi z założenia, że dobrą prognozą tempa i kosztów robót w przyszłości jest dotychczasowy przebieg robót, a więc obliczone dotychczas wskaźniki CPI i SPI.

$\mathrm{W}$ artykule przedstawiono analizę prognozy kosztów przedsięwzięcia budowlanego w zależności od metody wprowadzania zmiany terminu zakończenia robót $\mathrm{w}$ trakcie ich wykonywania i sposobu aktualizowania harmonogramu robót - zarówno w funkcji czasu, jak i rozkładu kosztów bez zmiany zakładanego kosztu końcowego $B A C$.

\section{MATERIAŁ I METODY}

\section{Założenia dotyczące zawieranego aneksu i wyznaczanej prognozy}

Wyznaczenie poprawnej prognozy nieco się komplikuje, gdy w trakcie wykonywania robót zlecający i wykonawca robót postanawiają podpisać aneks do zawartej wcześniej umowy, która stanowiła podstawę obowiązującego dotychczas rzeczowego i finansowego harmonogramu. Przyczyny aneksowania umowy o roboty budowlane mogą być różne, a najczęściej wynikają z:

- opóźnienia robót w stosunku do obowiązującego dotychczas harmonogramu i braku deklaracji wykonawcy o możliwości nadrobienia strat czasowych (zawinionych lub niezależnych od wykonawcy),

- zmiany (zazwyczaj wzrostu) cen materiałów, sprzętu i robocizny w stosunku do wartości, na podstawie których skalkulowany został budżet inwestycji $(B A C)$,

- zmiany zakresu robót objętych umową,

- kilku wymienionych czynników równocześnie.

Twórcy EVM wyróżnili dwa przypadki aneksowania (Webb, 2008):

- zmiana programu - gdy zmiana terminu robót $P D$ łączy się ze zmianą kosztów $B A C$,

- zmiana planu - gdy zmiana terminu robót $P D$ nie pociąga za sobą zmiany kosztów $B A C$.

$\mathrm{W}$ opisie metody można znaleźć zalecane techniki aneksowania przy zmianie programu, natomiast brak jest wskazówek postępowania przy zmianie planu. W artykule rozpatrzono właśnie ten aspekt aneksowania, a mianowicie przypadek, gdy aneks wydłuża pierwotnie planowany termin zakończenia robót $P D$ bez zmiany kosztów $B A C$. Przypadek ten jest jednym z częściej występujących w praktyce budowlanej podczas aneksowania zawartych umów. Analizę ograniczono również do prognozowania kosztu końcowego, bez prognozowania czasu.

Pomijając problem kar umownych, które mogą być konsekwencją zmiany warunków zawartej wcześniej umowy, każdy aneks stawia przed planistami problem zaktualizowania obowiązującego dotychczas harmonogramu. Sposób wprowadzenia tych zmian szczególnie jest istotny w sytuacji, gdy harmonogram jest podstawą do kontroli realizacji robót za pomocą EVM oraz obliczania prognoz kosztu i czasu wykonania całości realizowanych robót.

\section{Formuły obliczeniowe do wyznaczania prognozy kosztu}

W literaturze można spotkać wiele propozycji formuł obliczeniowych do prognozowania kosztu końcowego $E A C$. Generalnie większość z nich, ze względu na za- 
Połoński, M. (2019). Wpływ aneksowania terminu umowy na prognozę kosztu realizacji w metodzie wartości wypracowanej. Acta Sci. Pol. Architectura 18 (2), 69-78, DOI: 10.22630/ASPA.2019.18.2.24

kładany scenariusz postępu prac w przyszłości, można podzielić na trzy grupy:

- realizacja prac zgodnie z planem bazowym (Anbari, 2004),

- realizacja zgodnie z dotychczasowym trendem CPI (Department of Energy, 2003; Anbari, 2004; Webb, 2008),

- realizacja uwzględniająca dotychczasowe trendy CPI i SPI (Anbari, 2004; Athey, 2007; Webb, 2008; Starczyk-Kołbyk, 2018).

Z dotychczasowych badań wynika (Ziółkowska, 2014; Ziółkowska i Połoński, 2015, 2018), że najwiarygodniejsze prognozy uzyskiwano ze wzorów uwzględniających dotychczasowe wartości CPI. W związku z tym do dalszych analiz przyjęto sześć formuł (tab. 1). Trzy z nich zawierają wskaźnik CPI, dwie nie uwzględniają ani $C P I$, ani $S P I$, jedna zawiera zarówno CPI, jak i SPI.
Numeracja formuł $E A C$ została zachowana zgodnie $\mathrm{z}$ numeracją zastosowaną $\mathrm{w}$ pracy Ziółkowskiej (2014). Do analizy dołączono dla porównania jedną formułę uwzględniającą wartość SPI (Starczyk-Kołbyk, 2018). Wybrano właśnie tę formułę, gdyż w zaproponowanym wzorze na wynik prognozy stosunkowo w małym stopniu oddziałuje wartość SPI. Jak będzie można zauważyć, nawet w tym przypadku prognoza uwzględniająca SPI odbiega od pozostałych.

\section{Dane stanowiące podstawę wykonanych obliczeń}

Do analizy przyjęto przykładowy obiekt składający się z 10 zadań. Całkowity czas wykonania obiektu $P D$ założono na 20 miesięcy, a sumaryczny koszt realizacji $B A C$ obliczono na 10,2 mln PLN. Analizą kosztów objęto wyłącznie koszty bezpośrednie, aby nie zaburzać wyników analiz zmiennymi w czasie kosztami

Tabela 1. Formuły obliczeniowe prognozy kosztów uwzględnione w obliczeniach

Table 1. Cost calculation formulas included in the calculation

\begin{tabular}{|c|c|c|c|}
\hline $\begin{array}{l}\text { Źródło informacji } \\
\text { Source of information }\end{array}$ & $\begin{array}{l}\text { Wzór } \\
\text { Formuła }\end{array}$ & $\begin{array}{l}\text { Indeks wzoru } \\
\text { Index of formula }\end{array}$ & $\begin{array}{l}\text { Prognoza } \\
\text { Forecast }\end{array}$ \\
\hline Webb (2003) & $E A C=A C+(B A C-E V) / C P I$ & EAC1 & $\begin{array}{l}\text { realizacja prac zgodnie z panującym trendem } \\
C P I \\
\text { implementation of works in accordance with } \\
\text { the prevailing } C P I \text { trend }\end{array}$ \\
\hline Anbari (2003) & $E A C=A C+B A C-E V$ & EAC5 & $\begin{array}{l}\text { realizacja prac zgodnie } \mathrm{z} \text { planem bazowym } \\
\text { implementation of works in accordance with } \\
\text { the base plan }\end{array}$ \\
\hline Anbari (2003) & $E A C=B A C / C P I$ & EAC6 & $\begin{array}{l}\text { realizacja prac zgodnie z panującym trendem } \\
C P I \\
\text { implementation of works in accordance with } \\
\text { the prevailing } C P I \text { trend }\end{array}$ \\
\hline $\begin{array}{l}\text { Department of Energy } \\
\text { USA (2003) }\end{array}$ & $E A C=A C / E V \cdot B A C$ & EAC8 & $\begin{array}{l}\text { realizacja prac zgodnie z panującym trendem } \\
\text { implementation of works in accordance with } \\
\text { the prevailing trend }\end{array}$ \\
\hline $\begin{array}{l}\text { Department of Energy } \\
\text { USA (2003) }\end{array}$ & $E A C=A C+[1 / C P I(B A C-E V)]$ & $\mathrm{EAC} 10$ & $\begin{array}{l}\text { realizacja prac zgodnie z panującym trendem } \\
C P I \\
\text { implementation of works in accordance with } \\
\text { the prevailing } C P I \text { trend }\end{array}$ \\
\hline $\begin{array}{l}\text { Kołbyk-Starczyk } \\
(2018)\end{array}$ & $\begin{array}{c}E A C 1=A C+(B A C-E V) / \\
{[\text { pierwiastek }(0,5 C P I+0,5 S P I)]}\end{array}$ & EAC14 & $\begin{array}{l}\text { realizacja prac zgodnie z panującym trendem } \\
C P I \text { i } S P I \\
\text { implementation of works in accordance with } \\
\text { the prevailing } C P I \text { and } S P I \text { trend }\end{array}$ \\
\hline
\end{tabular}


Połoński, M. (2019). Wpływ aneksowania terminu umowy na prognozę kosztu realizacji w metodzie wartości wypracowanej. Acta Sci. Pol. Architectura 18 (2), 69-78, DOI: 10.22630/ASPA.2019.18.2.24

pośrednimi. Przyjęto terminy realizacji poszczególnych zadań i założono równomierne obciążenie kosztami każdego zadania. Pozwoliło to ustalić planowane skumulowane koszty w czasie, czyli przebieg krzywej $P V$ (rys. $1, P V 0)$.

Pierwszą aktualizację harmonogramu wykonano po pięciu miesiącach. Ustalono faktyczne zaawansowanie prac przy każdej czynności i na tej podstawie obliczono wartość wypracowaną $E V$ kolejnych zadań (tab. 3; wariant 0). Przyjęto również faktyczne koszty
$A C$ poniesione przez pięć miesięcy na wykonanie zakończonych prac. Sumaryczne wartości kosztów $P V$, $E V$ i $A C$ dla całego obiektu pozwoliły obliczyć wskaźniki: $C P I=0,910$ i $S P I=0,542$.

Obliczone wartości wskazują, że obiekt jest realizowany około $10 \%$ powyżej zaplanowanego kosztu i prace są mocno opóźnione w stosunku do planu (prawie o połowę). Przeprowadzona aktualizacja pozwoliła obliczyć prognozę całkowitych kosztów realizacji obiektu (tab. 2; wariant 0). Prognoza oparta na

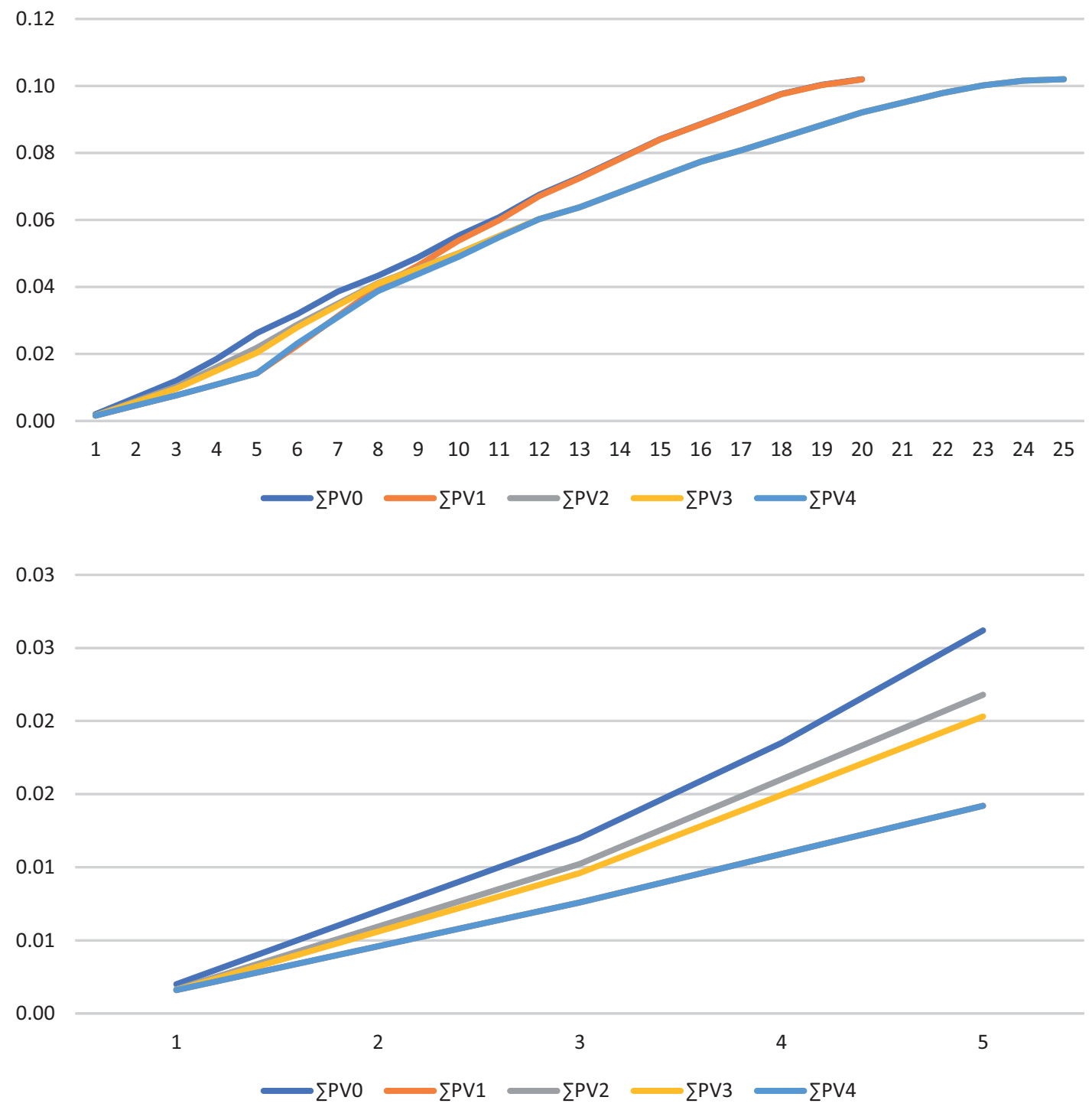

Rys. 1. Wykresy planowanych kosztów w całym okresie i do terminu aneksu

Fig. 1. Charts of planned costs in the entire period and up to the date of the annex 
Połoński, M. (2019). Wpływ aneksowania terminu umowy na prognozę kosztu realizacji w metodzie wartości wypracowanej. Acta Sci. Pol. Architectura 18 (2), 69-78, DOI: 10.22630/ASPA.2019.18.2.24

Tabela 2. Dane i prognoza kosztów dla kolejnych wariantów obliczeniowych

Table 2. Data and cost forecast for subsequent calculation options

\begin{tabular}{ccccccccccccc}
\hline $\begin{array}{c}\text { Wariant } \\
\text { Variant }\end{array}$ & $B A C$ & $P V$ & $E V$ & $A C$ & CPI & SPI & $E A C 1$ & $E A C 5$ & $E A C 6$ & $E A C 8$ & $E A C 10$ & $E A C 14$ \\
\hline 0 & 10,20 & 2,62 & 1,42 & 1,56 & 0,910 & 0,542 & 11,21 & 10,34 & 11,21 & 11,21 & 11,35 & 11,86 \\
1 & 10,20 & 1,42 & 1,42 & 1,56 & 0,910 & 1,000 & 11,21 & 10,34 & 11,21 & 11,21 & 11,35 & 10,54 \\
2 & 10,20 & 2,18 & 1,21 & 1,56 & 0,777 & 0,557 & 13,13 & 10,55 & 13,13 & 13,13 & 13,48 & 12,57 \\
3 & 10,20 & 1,42 & 1,42 & 1,56 & 0,729 & 0,561 & 14,00 & 10,62 & 14,00 & 14,00 & 14,42 & 12,85 \\
4 & 10,20 & 1,42 & 1,42 & 1,56 & 0,910 & 1,000 & 11,21 & 10,34 & 11,21 & 11,21 & 11,35 & 10,54 \\
\hline
\end{tabular}

planie bazowy (EAC5) wyznaczyła najmniejszą wartość (10,34 mln), prognoza z udziałem SPI największą $(11,87 \mathrm{mln})$, prognozy oparte na wskaźniku CPI koszty w zakresie 11,22-11,36 mln.

Po wyznaczeniu powyższej prognozy wprowadzono aneks do umowy, który wydłużył realizację $P D^{\prime}$ do 25 miesięcy, pozostawiając koszt $B A C$ bez zmiany. Próba kontynuowania kontroli realizacji obiektu i zastosowania EVM bez zmiany harmonogramu bardzo szybko doprowadzi do całkowitego zafałszowania rzeczywistych warunków panujących na placu budowy. Już w tym miejscu warto zauważyć, że sama zmiana terminu zakończenia $P D$ nie zmienia obliczonej wcześniej prognozy kosztów. Wynika to z tego, że wartość $P D$ nie wchodzi do żadnego wzoru na $E A C$ ani bezpośrednio, ani pośrednio przez wartość $C P I$ czy $S P I$. Jednak konieczność uwzględnienia wydłużonego terminu zakończenia robót stawia przed planistą problem sposobu uwzględnienia tej zmiany w harmonogramie, zwłaszcza w zakresie kosztów zadań w trakcie realizacji i jeszcze nierozpoczętych. Rozkład tych kosztów w czasie (rys. 1) ma zasadnicze znaczenie dla obliczenia prognozy kosztów $E A C$.

$\mathrm{Na}$ początku (wariant 1) sprawdzono, jakie wartości prognozy kosztów zostaną osiągnięte, gdy przy zmianie planu (a więc przy zmianie samego terminu) zostanie wdrożone postępowanie zalecane przy zmianie programu (a więc gdy zmienia się też koszt). Polega ono na przyjęciu do daty aktualizacji jako wartości planowanych $(P V)$ wartości faktycznie zrealizowane $(E V)$, pozostawiając wszystkie pozostałe wartości bez zmian w stosunku do wariantu 0 , a więc nie planując od nowa terminów zadań niedokończonych i nierozpo- czętych. Wówczas wartość wskaźnika $C P I$ pozostaje bez zmian $(0,910), S P I=1$, a wartości prognozy $E A C$ według wszystkich formuł przedstawiono w tabeli 2. Łatwo zauważyć, że jedyną zmienioną wartością prognozy jest $E A C 14=10,54$, zawierający w swojej formule wartość wskaźnika $S P I$, przy czym prognoza ta się obniżyła i jest zbliżona do dotychczasowej prognozy według planu bazowego $(E A C 5=10,34)$.

W kolejnej analizie sporządzono harmonogram, przyjmując założenie, że od początku wiadome było, że obiekt będzie realizowany w 25 miesięcy (tab. 1 i 2; wariant 2). Sumaryczne koszty wszystkich zadań pozostały bez zmian, lecz wydłużyły się ich czasy, a tym samym spadło miesięczne zapotrzebowanie na koszty (pozostawiono równomierny rozkład kosztów w czasie trwania zadań). Podczas aktualizacji po pięciu miesiącach przyjęto założenie, że wszystkie zadania zostały wykonane $\mathrm{w}$ takim samym stopniu co poprzednio, wyznaczono nowe wartości $P V$ i $E V$, a następnie obliczono CPI i SPI (odpowiednio 0,777 i 0,557$)$. Na podstawie takiego przeplanowania zadań obliczono prognozę kosztów $E A C$ (tab. 2). Prognoza według planu bazowego $(E A C 5=10,55 \mathrm{mln})$ pozostała prawie taka sama, natomiast wszystkie pozostałe prognozy wzrosły do poziomu $12,57-13,48 \mathrm{mln}$, przy czym najmniejsza prognoza została wyznaczona z udziałem wskaźnika $S P I(E A C 14=12,57 \mathrm{mln})$.

Trzeci wariant analizy obliczono przy założeniu 25 miesięcy realizacji, przeplanowanych zadaniach w czasie i zmienionym rozkładem kosztów na każdym zadaniu. Zadania zakończone pozostały bez zmian zarówno w funkcji czasu, jak i kosztów planowanych $P V$ i rzeczywistych $A C$ (ich ewentualne przeplanowanie 


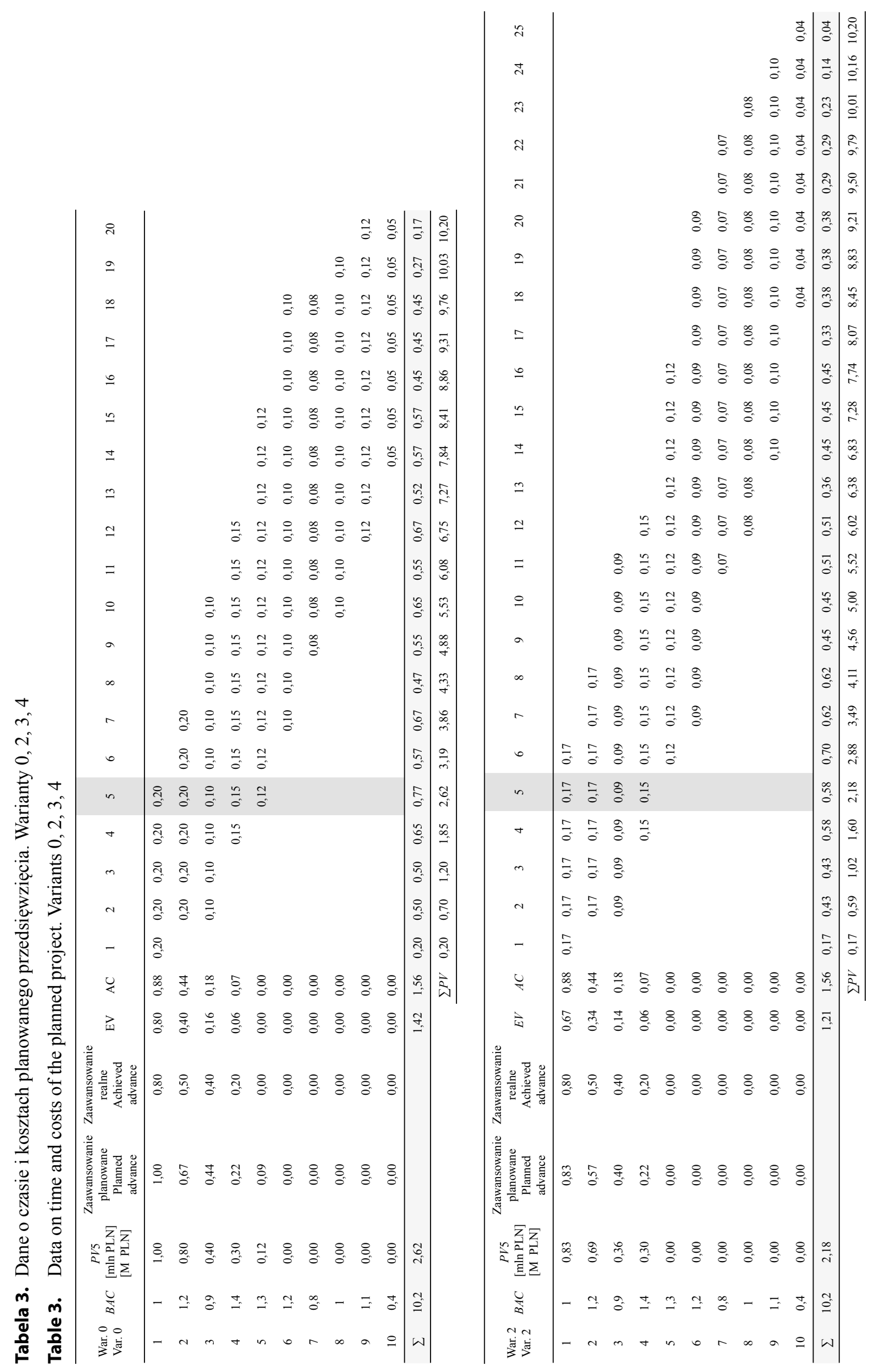




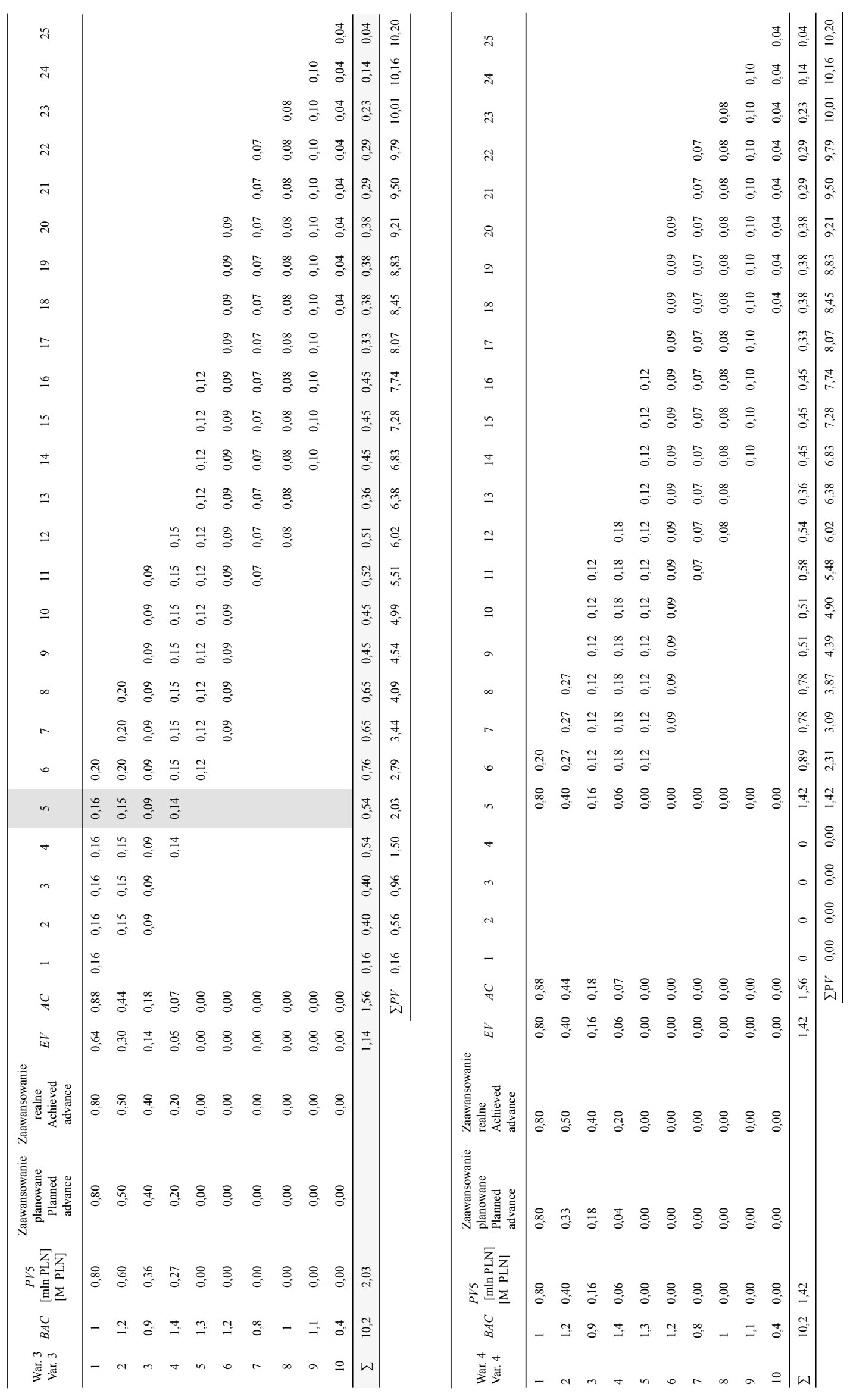


np. zgodnie $\mathrm{z}$ faktycznym wykonaniem nie zmieniło by wyników prognozy kosztów). Zadania w trakcie realizacji zostały przeplanowane $\mathrm{w}$ czasie, a ich planowane koszty podzielone na dwie części. Zakładając zawansowanie robót na każdym zadaniu takie same jak w poprzednich aktualizacjach, obliczono, jaka część kosztów planowanych dotyczyła części zrealizowanej, a jaka części niezrealizowanej. Obie części rozłożono równomiernie w czasie, oddzielnie w części zrealizowanej, oddzielnie w niezrealizowanej. Koszty zadań nierozpoczętych rozłożono równomiernie, zakładając nowe czasy (takie jak w wariancie 2) przeplanowanych zadań (tab. 3; wariant 3). Wyznaczono nowe wartości $P V$ i $E V$ (pozostawiając koszty $A C$ bez zmian) i obliczono nowe $C P I$ i $S P I$ (odpowiednio 0,729 i 0,561) oraz prognozy kosztów $E A C$ (tab. 2). Podobnie jak $\mathrm{w}$ wariancie 2 prognozy obliczone na podstawie planu bazowego $(E A C 5=10,62)$ i $S P I(E A C 14=12,85)$ pozostały na podobnych poziomach. Wszystkie pozostałe prognozy kolejny raz nieco wzrosły, oscylując na poziomie około $14 \mathrm{mln}$.

Ostatni wariant obliczeń (wariant 4) wykonano, zakładając te same terminy wykonania zadań jak w wariantach 2 i 3 , jednak inaczej rozkładając koszty na zadaniach. Przyjęto ponownie założenie, że do daty aktualizacji $P V$ równe jest $E V$ uzyskanej przed podpisaniem aneksu (wariant 0 ), a koszty części niezrealizowanej zadań rozłożono równomiernie $\mathrm{w}$ wydłużonych aneksem terminach poszczególnych zadań. Rozkład kosztów zadań nierozpoczętych pozostał bez zmian w porównaniu do wariantu 3 (tab. 3; wariant 4). Uzyskano $C P I=0,910$ i $S P I=1$.

Wartości prognozy kosztów EAC uzyskano dla wszystkich formuł takie same jak w wariancie 1 (poza $E A C 14)$-rysunek 2. Należy również zauważyć, że do obliczenia prognozy wystarczy znajomość sumy danych kosztów $(P V, E V, A C)$ w zadanym okresie, a nie znajomość ich szczegółowego rozkładu w czasie.

\section{PODSUMOWANIE I WNIOSKI}

Jak wykazały przeprowadzone obliczenia, jest kilka możliwych sposobów zmiany rozkładu kosztów zadań w trakcie wykonania i nierozpoczętych w harmonogramie, który ulega modyfikacji po podpisaniu aneksu i zmianie terminu zakończenia robót. Każdy z tych

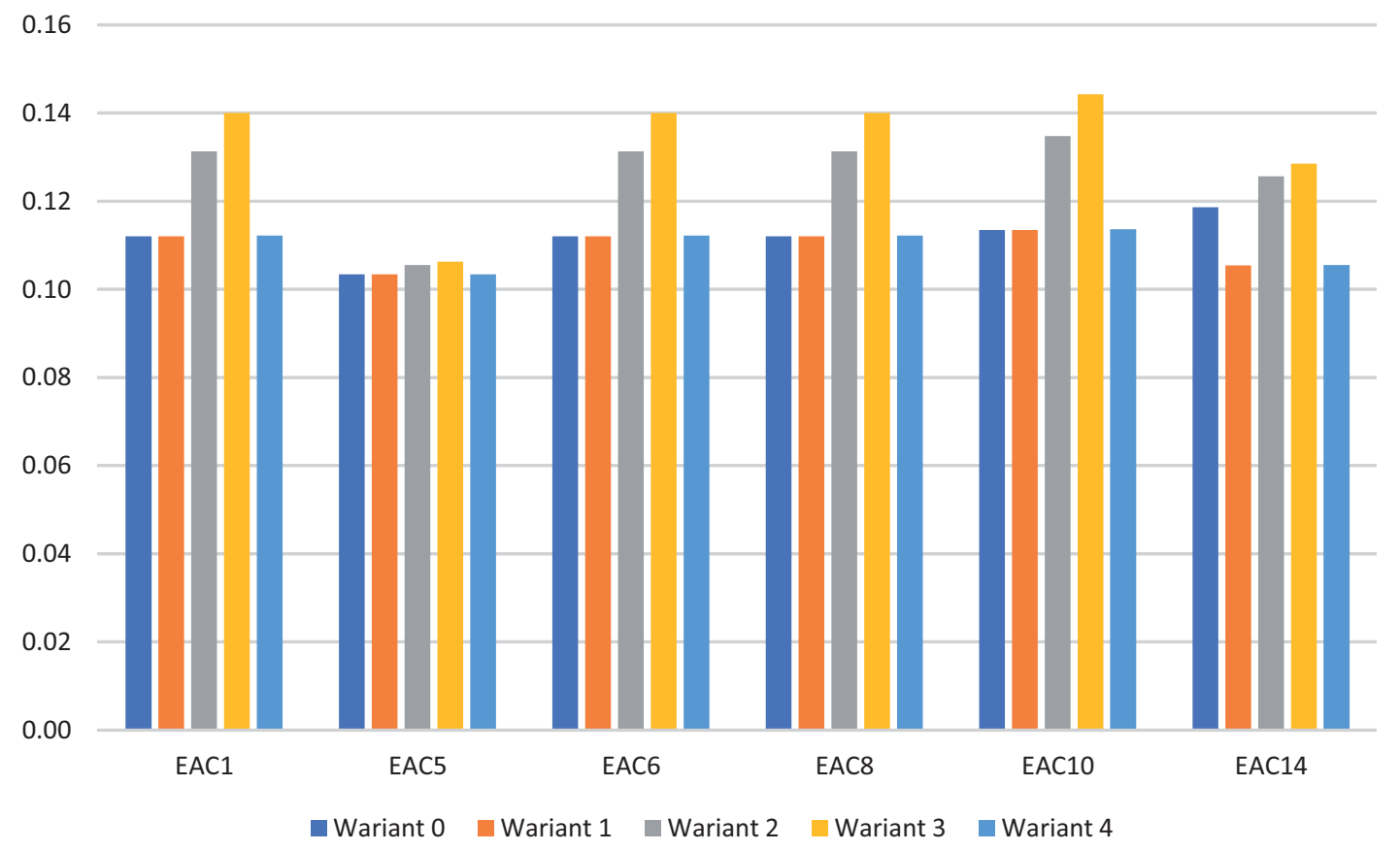

Rys. 2. Prognoza kosztów według kolejnych wariantów obliczeniowych

Fig. 2. Cost forecast for subsequent calculation variants 
Połoński, M. (2019). Wpływ aneksowania terminu umowy na prognozę kosztu realizacji w metodzie wartości wypracowanej. Acta Sci. Pol. Architectura 18 (2), 69-78, DOI: 10.22630/ASPA.2019.18.2.24

sposobów rzutuje na obliczenie prognozy kosztów końcowych $E A C$, przy czym uzyskany wynik w dużej mierze zależy również od formuły obliczeniowej zastosowanej do wyznaczenia tej prognozy.

Najbardziej stabilna prognoza otrzymywana jest z formuły $E A C 5$, która nie uwzględnia wskaźników CPI i SPI. Jej wartość podlega bardzo małym wahaniom, niezależnie od wprowadzonego aneksu i zastosowanego wariantu podziału kosztów. Należy jednak zauważyć, że wyznacza ona najmniejsze wartości prognozy. Stosując rozwiązanie $\mathrm{z}$ wariantu 4 , a więc przyjmując do daty aktualizacji $P V=E V$, a pozostałe koszty przenosząc na niewykonaną część zadań, uzyskujemy wyniki identyczne $\mathrm{z}$ prognozą sprzed podpisania aneksu. Wyjątkiem jest prognoza, w której uwzględniamy wskaźnik SPI. Po aneksie SPI przy przyjętych założeniach zawsze będzie równe jedności, więc różnica w prognozach przed podpisaniem aneksem i po tym będzie według tej formuły tym większa, im SPI sprzed zawarcia aneksu będzie bardziej odbiegać od 1 . Warianty 2 i 3 wyznaczają wyraźnie większe wartości prognozy kosztów niż pozostałe, z wyjątkiem formuły $E A C 5$.

Reasumując, jeżeli wprowadza się zmianę planowanego terminu zakończenia $P D$ według zapisów aneksu, należy zalecić rozwiązanie zastosowane $\mathrm{w}$ wariancie 4 . Takie rozwiązanie ma trzy zalety:

- umożliwia stworzenie zaktualizowanego harmonogramu dostosowanego do zmienionego terminu $P D$, stwarzającego warunki do efektywnego zarządzania obiektem w zmienionych warunkach,

- pozwala obliczyć prognozę kosztów przy zmienionym terminie $P D$, zgodną z prognozą sprzed podpisania aneksu,

- pozwala w przyszłości wykonać kolejne aktualizacje przebiegu robót i prognozy kosztów na podstawie harmonogramu, dostosowanego do realnego przebiegu robót na obiekcie.

Należy również zalecić, aby prognoza kosztów $E A C$ niezależnie od przyjętego wariantu uwzględniania aneksu wyznaczana była na podstawie kilku formuł obliczeniowych. Pozwoli to na oszacowanie prognozy nie jako wartości pewnej, ale w pewnym przedziale, w zależności od przyjętych założeń co do dalszego przebiegu robót.

\section{PIŚMIENNICTWO}

Anbari, F. T. (2004). Earned value project management method and extensions. IEEE Engineering Management Review, 34 (3), 12-23. https://doi.org/10.1109/ EMR.2004.25113

Athey, K. (2007). Earned Value Management - Current Solution and Roadmap to Adoption. Retrieved from http:// media.hypersites.com/clients/1105/filemanager/QPMEVMWhitepaper.pdf

Baumann, T., Dziadosz, A., Kapliński, O. i Rejment, M. (2014). Range of application and limitations of the earned value method in construction project estimation. Technical Transactions, 111 (2-B), 65-72. Retrieved from https://suw.biblos.pk.edu.pl/resourceDetailsRPKi$\mathrm{rId}=44673$

Czarnigowska, A., Jaskowski, P. i Biruk, S. (2011). Project Performance Reporting and Prediction: Extensions of Earned Value Management. International Journal Of Business And Management Studies, 3 (1), 11-20. Retrieved from http://www.sobiad.org/ejournals/ journal_ijbm/arhieves/2011_Vol_3_no_1/02agata_ czarnigowska.pdf

Department of Energy, USA (2003). EVM Tutorials, Module 1-8. Retrieved from http://energy.gov/management/office-management/operational-management/project-management/earned-value-management [accessed: 12.02.2019].

Dziadosz, A., Tomczyk, A. i Kapliński, O. (2015). Financial Risk Estimation in Construction Contracts. Procedia Engineering, 122, 120-128. https://doi.org/10.1016/ J.PROENG.2015.10.015

Połoński, M. (2015). Kontrola kosztów realizacji obiektu budowlanego metodą Earned Value. W T. Kasprowicz (red.), Inżynieria przedsięwzięć budowlanych: Rekomendowane metody i techniki (strony 81-125). Warszawa: SIPB KILiW PAN.

Starczyk-Kołbyk, A. (2018). Randomizowana metoda identyfikacji stanu zaawansowania robót i korekty planu budowy (nieopublikowana rozprawa doktorska). Wojskowa Akademia Techniczna, Warszawa.

Webb, A. (2008). Wartość wypracowana w praktyce. Olsztyn: PROED.

Ziółkowska, A. (2014). Wspomaganie realizacji przedsięwzięcia budowlanego z wykorzystaniem metody wartości wypracowanej (nieopublikowana rozprawa doktorska). SGGW, Warszawa.

Ziółkowska, A. i Połoński, M. (2015). Application of the EVM method and its extensions in the implementation 
of construction objects. Engineering Structures and Technologies, 7 (4), 189-196. https://doi.org/10.3846/ 2029882X.2016.1152168

Ziółkowska, A. i Połoński, M. (2018). Prognozowanie w metodzie EVM terminu i kosztu końcowego realizacji obiektu na podstawie bieżącego zaawansowania.
W A. Sobotka, E. Radziszewska-Zielina (red.), Inżynieria przedsięwzięć budowlanych: problemy, modele, metody (pp. 207-234). Warszawa-Kraków: KILiW PAN. Retrieved from http://mieczyslaw_polonski.users.sggw. pl/Strony207_234Mon_99_all.pdf

\section{THE EFFECT OF AN ANNEXATION OF THE CONTRACT'S DEADLINE FOR THE ESTIMATION OF THE COST OF IMPLEMENTATION IN THE EVM METHOD}

\section{ABSTRACT}

The earned value method (EVM) is an increasingly popular tool for controlling the implementation of construction works, both in material and financial terms. One of the valuable possibilities of this method is forecasting the cost of final works based on the current progress of works and incurred financial outlays. However, due to the frequent occurrence of a delay set in the construction contract for the completion of works, the annex is signed. It may refer to the postponement of the ending date, change of the planned execution costs or both, simultaneously. The article raises the problem of the impact of changes to the planned date of completion of works on the calculation of the forecast of its final cost. As shown in the examples, the method of including changes in the term in the EVM has a significant impact on the result of the forecast. The article indicates the recommended solution, allowing for the necessary modification of the schedule and correct estimation of the final cost.

Key words: building object, earned value method, EVM, estimation of cost, annex, project control 